\title{
FAKTOR-FAKTOR YANG BERHUBUNGAN DENGAN PARTISIPASI AKSEPTOR KB AKTIF TERHADAP PENGGUNAAN KONTRASEPSI JANGKA PANJANG DI DESA CIGALONTANG WILAYAH KERJA PUSKESMAS CIGALONTANG TAHUN 2018
}

\author{
Hapi Apriasih, SST.,M.Kes 1) \\ py.anbyan@gmail.com \\ Tupriliany Danefi, SST.,M.Kes
tuprilianydanefi07@gmail.com
}

\section{A. ABSTRAK}

Jumlah penduduk di Indonesia dari tahun ke tahun semakin meningkat jumlahnya sehingga menempatkannya di urutan keempat sebagai negara dengan jumlah penduduk terbesar didunia. Menurut data Survei Demografi dan Kesehatan Indonesia (SDKI) 2017 menunjukkan bahwa pemakaian kontrasepsi di antara wanita berstatus kawin di Indonesia meningkat dari 60\% pada tahun 2002-2003 menjadi 63,3\%. Peningkatan terbanyak terjadi pada pemakaian metode kontrasepsi suntik. Pemakaian IUD menurun selama kurun waktu 10 tahun terakhir. Dalam RPJMN 2015 - 2019 tertulis bahwa program pemerintah untuk lima tahun kedepan salah satunya adalah Peningkatan pelayanan KB dengan menggunakan MKJP. Dalam Notoatmodjo (2005) rendahnya jumlah Pengguna Metode Kontrasepsi Jangka Panjang (MKJP), dipengaruhi oleh beberapa faktor diantaranya adalah faktor predisposing yaitu faktor pengetahuan, nilai atau kepercayaan dan sikap, serta faktor pemungkin yaitu fasilitas, biaya, jarak dan ketersediaan trasnfortasi sedangkan faktor penguat yaitu dari dukungan suami dan keluarga

Tujuan penelitian ini adalah untuk mengetahui faktor-faktor yang berhubungan dengan partisipasi akseptor KB aktif terhadap penggunaan kontrasepsi jangka panjang di Desa Cigalontang Wilayah Kerja PKM Cigalontang tahun 2018. Jenis penelitian yang digunakan dalam penelitian ini adalah penelitian kuantitatif analitik dengan desain cross sectional. Analisa yang digunakan adalah analisa univariat dan bivariat. Populasi dalam penelitian ini adalah seluruh akseptor KB aktif dengan tekhnik pengambilan sampel menggunakan total sampling sebanyak 448 akseptor KB aktif.

Berdasarkan hasil penelitian didapatkan bahwa 85\% responden menggunakan metode kontrasepsi jangka panjang (MKJP) dan 15\% responden tidak menggunakan MKJP. Hasil tabulasi silang didapatkan faktor yang berhubungan dengan partisipasi akseptor KB aktif terhadap penggunaan MKJP adalah paritas ( $p$ value 0,000), pekerjaan ( $p$ value 0,000), status sosio ekonomi ( $p$ value 0,000), dan dukungan suami ( $p$ value 0,000$)$ dengan $<$ alpha $(0,05)$, sedangkan variabel pengetahuan ( $p$ value 0,164), dan sikap ( $p$ value 0,071) tidak berhubungan dengan penggunaan kontrasepsi jangka panjang dengan $>$ alpha $(0,05)$.

Simpulan dalam penelitian ini adalah terdapat hubungan antara paritas, pekerjaan, status sosio ekonomi, dukungan suami dengan penggunaan kontrasepsi MKJP dan tidak ada hubungan antara pengetahuan dan sikap dengan penggunaan kontrasepsi MKJP. Saran meningkatkan konseling $K B$ pada calon akseptor $K B$ oleh tenaga kesehatan sehingga dapat meningkatkan pemahaman tentang metode MKJP dengan menggunakan media yang efektif serta meningkatkan keterlibatan suami dalam ber KB.

Kata Kunci : Paritas, Pekerjaan, Status Sosio Ekonomi, Dukungan Suami 


\section{A. PENDAHULUAN}

Dengan laju pertumbuhan yang masih relatif tinggi, jumlah penduduk di Indonesia dari tahun ke tahun semakin meningkat jumlahnya sehingga menempatkannya di urutan keempat sebagai negara dengan jumlah penduduk terbesar didunia. Dalam hal ini tugas program Keluarga Berencana (KB) telah jelas yaitu bagaimana menurunkan fertilitas agar dapat mengurangi beban pembangunan demi terwujudnya kebahagiaan dan kesejahteraan bagi rakyat dan bangsa Indonesia, dimana angka kelahiran total atau Total Fertility Rate (TFR) di Indonesia masih di angka 2,6

sedangkan target dalam rencana pembangunan jangka menengah nasional tahun 2015- 2019 menjadi 2,28 anak perwanita dengan penggunaan metode kontrasepsi yang tepat (Manuaba, 2010).

Menurut data Survei Demografi dan Kesehatan Indonesia (SDKI) 2017 menunjukkan bahwa pemakaian kontrasepsi di antara wanita berstatus kawin di Indonesia meningkat dari $60 \%$ pada tahun 2002-2003 menjadi 63,3\%. Peningkatan terbanyak terjadi pada pemakaian metode kontrasepsi suntik. Peningkatan pemakaian suntik KB diiringi oleh turunnya peserta IUD, pil dan implan. Pemakaian IUD menurun selama kurun waktu 10 tahun terakhir.

Dalam RPJMN 2015 - 2019 tertulis bahwa program pemerintah untuk lima tahun kedepan salah satunya adalah Peningkatan pelayanan KB dengan menggunakan MKJP. Dikarenakan efek samping dari MKJP lebih sedikit, dan

efektivitas MKJP lebih tinggi dibandingkan dengan non MKPJ, sehingga program pemerintah 2 anak lebih baik yang bertujuan untuk menekan laju penduduk dapat terealisasikan.
Pemerintah telah melakukan berbagai upaya untuk meningkatkan penggunaan MKJP di antaranya dengan menyelenggarakan kegiatan safari Keluarga Berencana (KB). Kelangsungan dalam penggunaan MKJP terutama pada akseptor yang berpartisipasi dalam kegiatan safari KB harus dijaga agar upaya pemerintah ini mencapai hasil yang diharapkan. (Sistri, 2009).

Menurut green (1980) dalam Notoatmodjo (2005) rendahnya jumlah Pengguna Metode Kontrasepsi Jangka Panjang (MKJP), dipengaruhi oleh beberapa faktor diantaranya adalah faktor predisposing yaitu faktor pengetahuan, nilai atau kepercayaan dan sikap, serta faktor pemungkin yaitu fasilitas, biaya, jarak dan ketersediaan trasnfortasi sedangkan faktor penguat yaitu dari dukungan suami dan keluarga, sejalan dengan penelitian Berdasarkan penelitian yang dilakukan oleh Fienalia (2012), variabel pengetahuan memiliki hubungan dengan penggunaan MKJP. Akseptor KB yang memiliki pengetahuan tinggi memiliki peluang sebesar 2.6 kali lebih besar. untuk menggunakan MKJP. Sejalan dengan penelitian tersebut, hasil penelitian yang dilakukan oleh Purba (2009) menyatakan bahwa ada hubungan yang signifikan antara variabel pengetahuan, sikap, dan dukungan suami terhadap penggunaan MKJP. Sementara pada analisis lanjutan SDKI 2007 yang dilakukan oleh Asih dan Hadriah (2009) menyatakan bahwa terdapat hubungan yang bermakna antara keterpaparan informasi KB dengan penggunaan MKJP.

Berdasarkan data dinas kesehatan Kab Tasikmalaya tahun 2016, wilayah kecamatan cigalontang merupakan wilayah dengan jumlah pengguna MKJP kedua terendah setelah pancatengah yaitu hanya $8,2 \%$ terdiri dari IUD 585 akseptor (3,9\%), MOP 158 akseptor (1,1\%), MOW 106 akseptor $(0,7 \%)$, dan implan 385 akseptor (2,6\%). Sedangkan akseptor 
pengguna non MKJP sebanyak 91,8 \% yang sebagian besar terdiri dari pengguna akseptor KB suntik yaitu 12,580 akseptor $(83,7 \%)$. Dari data tersebut dapat

disimpulkan penggunaan metode kontrasepsi jangka panjang di cigalontang masih menjadi pilihan minoritas dibandingkan dengan kontrasepsi lainnya yang didominasi oleh akseptor KB suntik, sedangkan kontrasepsi MKJP banyak

\section{B. METODE PENELITIAN}

Jenis penelitian yang digunakan dalam penelitian ini adalah jenis penelitian kuantitatif analitik dengan desain cross sectional. Populasi dalam penelitian ini adalah akseptor $\mathrm{KB}$ aktif dengan teknik pengambilan sampel menggunakan total sampling didapatkan sampel sebanyak 448 akseptor KB aktif. Tempat penelitian di Desa Cigalontang Kecamatan Singaparna Kabupaten Tasikmalaya tahun 2018. Teknik pengumpulan data yang digunakan memberikan keuntungan dan efek samping yang terjadi lebih sedikit.

Berdasarkan uraian di atas, peneliti ingin mengetahui faktor-faktor yang berhubungan dengan rendahnya partisipasi akseptor KB aktif terhadap penggunaan kontrasepsi jangka panjang di desa cigalontang wilayah kerja Puskesmas Cigalontang Tahun 2018. dalam penelitian ini dengan data primer. Analisis yang digunakan dalam penelitian ini adalah analisis univariat untuk menggambarkan distribusi dan frekuensi penggunaan kontrasepsi MKJP, pekerjaan, paritas, dukungan suami, status sosio ekonomi, pengetahuan, sikap dan analisis bivariat untuk mengetahui hubungan faktor pekerjaan, paritas, dukungan suami, status sosio ekonomi, pengetahuan, sikap dengan partisipasi akseptor KB aktif terhadap penggunaan MKJP.

\section{HASIL PENELITIAN}

Hasil penelitian mengenai faktor-faktor yang berhubungan dengan partisipasi akseptor KB aktif terhadap penggunaan MKJP adalah sebagai berikut:

1. Penggunaan Kontrasepsi MKJP

Gambar 3.1 Distribusi frekuensi Akseptor KB Aktif Terhadap Penggunaan Kontrasepsi Jangka Panjang di Wilayah Kerja Puskesmas Cigalontang Kabupaten Tasikmalaya tahun 2018

\begin{tabular}{|l|c|c|}
\hline \multicolumn{1}{|c|}{ Pemilihan kontrasepsi } & Jumlah & Persentase (\%) \\
\hline MKJP & 73 & 15 \\
\hline NON MKJP & 415 & 85 \\
\hline Jumlah & 488 & 100 \\
\hline
\end{tabular}

Berdasarkan gambar 3.1 menunjukkan bahwa sebagian besar responden tidak menggunakan metode kontrasepsi jangka panjang sebanyak 415 orang $(85 \%)$, dan terdapat 73 orang $(85 \%)$ responden menggunakan metode kontrasepsi jangka panjang, adapun distribusi responden yang menggunakan metode kontrasepsi jangka panjang adalah MOW sebanyak 5 orang $(6,85 \%)$, IUD sebanyak 45 orang $(61,65 \%)$, dan implant sebanyak 23 orang $(31,5$ $\%)$. 


\section{Pengetahuan}

Tabel 3.2 Distribusi frekuensi Pengetahuan Akseptor KB Pengguna MKJP Terhadap Penggunaan Kontrasepsi Jangka Panjang

di Wilayah Kerja Puskesmas Cigalontang Kabupaten Tasikmalaya tahun 2018

\begin{tabular}{|l|c|c|}
\hline \multicolumn{1}{|c|}{ Pengetahuan } & Jumlah & Persentase (\%) \\
\hline Baik & 37 & 50.7 \\
\hline Kurang & 36 & 49.3 \\
\hline Jumlah & 73 & 100 \\
\hline
\end{tabular}

Berdasarkan Tabel 3.2 menunjukkan bahwa komposisi pengetahuan responden pengguna MKJP antara pengetahuan yang baik dan yang pengetahuan kurang hampir sama yaitu kategori baik sebanyak 37 orang (50,7 \%) dan kategori kurang sebanyak 36 orang (49.3).

\section{Sikap}

Tabel 3.3 Distribusi frekuensi Sikap Akseptor KB Pengguna MKJP Terhadap Penggunaan Kontrasepsi Jangka Panjang di Wilayah Kerja Puskesmas Cigalontang Kabupaten Tasikmalaya tahun 2018

\begin{tabular}{|l|c|c|}
\hline \multicolumn{1}{|c|}{ Sikap } & Jumlah & Persentase (\%) \\
\hline Positif & 4 & 5.5 \\
\hline Negatif & 69 & 94.5 \\
\hline Jumlah & 73 & 100 \\
\hline
\end{tabular}

Berdasarkan Tabel 3.3 menunjukkan bahwa sikap sebagian besar responden MKJP terhadap penggunaan metode kontrasepsi jangka panjang adalah negatif yaitu sebanyak 69 orang $(94.7 \%)$ sedangkan responden yang mempunyai sikap positif hanya terdapat 4 orang $(5.5 \%)$.

\section{Pekerjaan}

Tabel 3.4 Distribusi frekuensi Pekerjaan Akseptor KB Pengguna

MKJP Terhadap Penggunaan Kontrasepsi Jangka Panjang

di Wilayah Kerja Puskesmas Cigalontang

Kabupaten Tasikmalaya tahun 2018

\begin{tabular}{|l|c|c|}
\hline \multicolumn{1}{|c|}{ Pekerjaan } & Jumlah & Persentase (\%) \\
\hline Bekerja & 20 & 27.4 \\
\hline Tidak Bekerja & 53 & 72.6 \\
\hline Jumlah & 73 & 100 \\
\hline
\end{tabular}

Tabel 3.4 menunjukkan bahwa pekerjaan sebagian besar responden akseptor KB aktif MKJP adalah tidak bekerja yaitu 53 orang (72.6\%) sedangkan responden yang bekerja sebanyak 20 orang $(27.4 \%)$. 


\section{Paritas}

Tabel 3.5 Distribusi frekuensi Paritas Akseptor KB Pengguna MKJP Terhadap Penggunaan Kontrasepsi Jangka Panjang di Wilayah Kerja Puskesmas Cigalontang Kabupaten Tasikmalaya tahun 2018

\begin{tabular}{|l|c|c|}
\hline \multicolumn{1}{|c|}{ Paritas } & Jumlah & Persentase (\%) \\
\hline Ideal & 28 & 38.4 \\
\hline Tidak Ideal & 45 & 61.6 \\
\hline Jumlah & 73 & 100 \\
\hline
\end{tabular}

Tabel 3.5 menunjukkan bahwa paritas sebagian besar responden akseptor KB aktif MKJP adalah tidak ideal yaitu 45 orang $(61.6 \%)$ sedangkan responden dengan paritas tidak ideal sebanyak 28 orang $(38.4 \%)$.

\section{Status Ekonomi}

Tabel 3.6 Distribusi frekuensi Status Ekonomi Akseptor KB Pengguna MKJP Terhadap Penggunaan Kontrasepsi Jangka Panjang di Wilayah Kerja Puskesmas Cigalontang Kabupaten Tasikmalaya tahun 2018

\begin{tabular}{|c|c|c|}
\hline Status ekonomi & Jumlah & Persentase (\%) \\
\hline$>$ UMR & 15 & 20.5 \\
\hline$<$ UMR & 58 & 79.5 \\
\hline Jumlah & 73 & 100 \\
\hline
\end{tabular}

Tabel 3.6 menunjukkan bahwa status ekonomi sebagian besar responden akseptor KB aktif MKJP adalah dibawah UMR yaitu 58 orang (79.5\%) sedangkan responden dengan status ekonomi diatas UMR sebanyak 15 orang $(29.5 \%)$.

\section{Dukungan Suami}

Tabel 3.7 Distribusi frekuensi Dukungan Suami Pada Akseptor KB Pengguna MKJP Terhadap Penggunaan Kontrasepsi Jangka Panjang di Wilayah Kerja Puskesmas

\section{Cigalontang Kabupaten Tasikmalaya tahun 2018}

\begin{tabular}{|l|c|c|}
\hline \multicolumn{1}{|c|}{ Dukungan Suami } & Jumlah & Persentase (\%) \\
\hline Mendukung & 54 & 74 \\
\hline Tidak Mendukung & 19 & 26 \\
\hline Jumlah & 73 & 100 \\
\hline
\end{tabular}

Data pada tabel 3.7 menunjukkan bahwa sebagian besar suami mendukung akseptor KB aktif MKJP terhadap penggunaan metode kontrasepsi jangka panjang yaitu 54 orang (74 \%) sedangkan sebagian kecil suami yang tidak mendukung sebanyak 19 orang (26\%). 


\section{Hubungan pengetahuan dengan penggunaan kontrasepsi MKJP}

Tabel 3.8 Hubungan Antara Pengetahuan Akseptor KB Aktif dengan Penggunaan Kontrasepsi Jangka Panjang di Wilayah Kerja Puskesmas Cigalontang Kabupaten Tasikmalaya tahun 2018

\begin{tabular}{|c|c|c|c|c|c|c|c|}
\hline \multirow{3}{*}{ Pengetahuan } & \multicolumn{4}{|c|}{ Penggunaan kontrasepsi } & \multirow{2}{*}{\multicolumn{2}{|c|}{ Total }} & \multirow{3}{*}{ P value } \\
\hline & \multicolumn{2}{|c|}{ MKJP } & \multicolumn{2}{|c|}{ Non MKJP } & & & \\
\hline & $\mathbf{F}$ & $\%$ & $\mathbf{F}$ & $\%$ & Jml & $(\%)$ & \\
\hline Baik & 37 & 17.5 & 174 & 82.5 & 211 & 100 & $0_{1}$ \\
\hline Kurang & 36 & 13 & 241 & 87 & 277 & 100 &, 164 \\
\hline Jumlah & 73 & 15 & 415 & 85 & 448 & 100 & \\
\hline
\end{tabular}

Data pada tabel 5.15 menunjukkan bahwa sebanyak 174 orang (82.5\%) responden yang mempunyai pengetahuan baik tidak menggunakan kontrasepsi jangka panjang dan sebanyak 241 orang $(87 \%)$ responden yang mempunyai pengetahuan kurang tidak menggunakan kontrasepsi jangka panjang. Berdasarkan hasil analisis didapat $\mathrm{p}$ value sebesar 0,164 artinya tidak ada hubungan antara pengetahuan dengan penggunaan metode kontrasepsi jangka panjang.

9. Hubungan sikap dengan penggunaan kontrasepsi MKJP

Tabel 3.9 Hubungan Antara Sikap Akseptor KB Aktif dengan Penggunaan Kontrasepsi Jangka Panjang di Wilayah Kerja Puskesmas Cigalontang Kabupaten Tasikmalaya tahun 2018

\begin{tabular}{|c|c|c|c|c|c|c|c|}
\hline \multirow{3}{*}{ Sikap } & \multicolumn{3}{|c|}{ Penggunaan kontrasepsi } & \multicolumn{2}{|c|}{ Total } & \multirow{2}{*}{ P value } \\
\cline { 2 - 5 } & \multicolumn{2}{|c|}{ MKJP } & \multicolumn{2}{|c|}{ Non MKJP } & \multicolumn{2}{|c|}{} \\
\cline { 2 - 5 } & F & $\mathbf{\%}$ & F & \% & Jml & (\%) & \\
\hline Positif & 4 & 33.3 & 8 & 66.7 & 12 & 100 & \multirow{2}{*}{0,071} \\
\hline Negatif & 69 & 14.5 & 407 & 85.5 & 476 & 100 & \\
\hline Jumlah & 73 & 15 & 415 & 85 & 448 & 100 & \\
\hline
\end{tabular}

Data pada tabel 3.9 menunjukkan bahwa sebanyak 8 orang $(66.7 \%)$ responden yang mempunyai respon sikap yang positif terhadap penggunaan metode jangka panjang tidak menggunakan kontrasepsi jangka panjang dan sebanyak 407 orang $(85.5 \%)$ responden yang mempunyai respon sikap negatif terhadap penggunaan kontrasepsi jangka panjang tidak menggunakan kontrasepsi jangka panjang. Berdasarkan hasil analisis didapat $\mathrm{p}$ value sebesar 0,071 artinya tidak ada hubungan antara pengetahuan dengan penggunaan metode kontrasepsi jangka panjang. 


\section{Hubungan Pekerjaan dengan penggunaan kontrasepsi MKJP}

Tabel 3.10 Hubungan Antara Pekerjaan Akseptor KB Aktif dengan Penggunaan Kontrasepsi Jangka Panjang di Wilayah Kerja Puskesmas Cigalontang Kabupaten Tasikmalaya tahun 2018

\begin{tabular}{|c|c|c|c|c|c|c|c|c|}
\hline \multirow{3}{*}{ Pekerjaan } & \multicolumn{4}{|c|}{ Penggunaan kontrasepsi } & \multirow{2}{*}{\multicolumn{2}{|c|}{ Total }} & \multirow{3}{*}{ P value } & \multirow{3}{*}{ OR } \\
\hline & \multicolumn{2}{|c|}{ MKJP } & \multicolumn{2}{|c|}{ Non MKJP } & & & & \\
\hline & $\mathbf{F}$ & $\%$ & $\mathbf{F}$ & $\%$ & $\mathbf{J m l}$ & $(\%)$ & & \\
\hline Bekerja & 20 & 30.8 & 45 & 69.2 & 85 & 100 & \multirow[b]{2}{*}{0,000} & \multirow[b]{2}{*}{3,094} \\
\hline $\begin{array}{l}\text { Tidak } \\
\text { Bekerja }\end{array}$ & 53 & 12.6 & 369 & 87.4 & 422 & 100 & & \\
\hline Jumlah & 73 & 15 & 415 & 85 & 448 & 100 & & \\
\hline
\end{tabular}

Data pada tabel 3.10 menunjukkan bahwa sebanyak 45 orang (69.2\%) responden yang bekerja tidak menggunakan kontrasepsi jangka panjang dan sebanyak 369 orang $(87.4 \%)$ responden yang tidak bekerja tidak menggunakan kontrasepsi jangka panjang. Berdasarkan hasil analisis didapat $\mathrm{p}$ value sebesar 0,000 artinya terdapat hubungan antara pekerjaan dengan penggunaan metode kontrasepsi jangka panjang. Responden yang bekerja berpeluang sebesar 3.094 kali untuk menggunakan kontrasepsi jangka panjang dibandingkan dengan responden yang tidak bekerja.

\section{Hubungan paritas dengan penggunaan kontrasepsi MKJP}

Tabel 3.11 Hubungan Antara Paritas Akseptor KB Aktif dengan Penggunaan Kontrasepsi Jangka Panjang di Wilayah Kerja Puskesmas Cigalontang Kabupaten Tasikmalaya tahun 2018

\begin{tabular}{|c|c|c|c|c|c|c|c|c|}
\hline \multirow{3}{*}{ Paritas } & \multicolumn{4}{|c|}{ Penggunaan kontrasepsi } & \multirow{2}{*}{\multicolumn{2}{|c|}{ Total }} & \multirow{3}{*}{$\begin{array}{c}\mathrm{P} \\
\text { value }\end{array}$} & \multirow{3}{*}{ OR } \\
\hline & \multicolumn{2}{|c|}{ MKJP } & \multicolumn{2}{|c|}{ Non MKJP } & & & & \\
\hline & $\mathbf{F}$ & $\%$ & $\mathbf{F}$ & $\%$ & Jml & $(\%)$ & & \\
\hline Ideal & 28 & 9.2 & 278 & 90.8 & 306 & 100 & \multirow{2}{*}{0,000} & \multirow{2}{*}{0,307} \\
\hline Tidak & 45 & 24.7 & 137 & 75.3 & 182 & 100 & & \\
\hline Jumlah & 73 & 15 & 415 & 85 & 448 & 100 & & \\
\hline
\end{tabular}

Data pada tabel 3.11 menunjukkan bahwa sebanyak 278 orang $(90.8 \%)$ responden dengan paritas ideal tidak menggunakan kontrasepsi jangka panjang dan sebanyak 137 orang $(75.3 \%)$ responden dengan paritas tidak ideal tidak menggunakan kontrasepsi jangka panjang. Berdasarkan hasil analisis didapat $p$ value sebesar 0,000 artinya terdapat hubungan antara paritas dengan penggunaan metode kontrasepsi jangka panjang. Responden dengan paritas tidak ideal berpeluang sebesar 0.307 kali untuk menggunakan kontrasepsi jangka panjang dibandingkan dengan responden dengan paritas ideal. 
12. Hubungan Status Sosio Ekonomi dengan penggunaan kontrasepsi MKJP

Tabel 3.12 Hubungan Antara Status Ekonomi Akseptor KB Aktif dengan

Penggunaan Kontrasepsi Jangka Panjang di Wilayah Kerja

Puskesmas Cigalontang Kabupaten Tasikmalaya tahun 2018

\begin{tabular}{|l|c|c|c|c|c|c|c|c|}
\hline \multirow{3}{*}{ Penghasilan } & \multicolumn{4}{|c|}{ Penggunaan kontrasepsi } & \multicolumn{2}{|c|}{ Total } & \multirow{2}{*}{ P value } & \multirow{2}{*}{ OR } \\
\cline { 2 - 6 } & \multicolumn{2}{|c|}{ MKJP } & \multicolumn{2}{|c|}{ Non MKJP } & \multicolumn{2}{|c|}{} \\
\cline { 2 - 7 } & $\mathbf{F}$ & $\mathbf{\%}$ & $\mathbf{F}$ & $\mathbf{\%}$ & $\mathbf{J m l}$ & $\mathbf{( \% )}$ & & \\
\hline$>$ UMR & 15 & 33.3 & 30 & 66.7 & 45 & 100 & \multirow{2}{*}{0,013} & \multirow{2}{*}{3,319} \\
\hline < UMR & 58 & 13.1 & 385 & 86.9 & 443 & 100 & & \\
\hline Jumlah & 73 & 15 & 415 & 85 & 448 & 100 & & \\
\hline
\end{tabular}

Data pada tabel 3.12 menunjukkan bahwa sebanyak 30 orang (66.7\%) responden dengan status ekonomi diatas UMR tidak menggunakan kontrasepsi jangka panjang dan sebanyak 385 orang $(86.9 \%)$ responden dengan status ekonomi dibawah UMR tidak menggunakan kontrasepsi jangka panjang. Berdasarkan hasil analisis didapat $\mathrm{p}$ value sebesar 0,013 artinya terdapat hubungan antara paritas dengan penggunaan metode kontrasepsi jangka panjang. Responden dengan status ekonomi diatas UMR berpeluang sebesar 3.319 kali untuk menggunakan kontrasepsi jangka panjang dibandingkan dengan responden dengan status ekonomi dibawah UMR.

\section{Hubungan Dukungan Suami dengan penggunaan kontrasepsi MKJP}

Tabel 3.13 Hubungan Antara Dukungan Suami Akseptor KB Aktif dengan

Penggunaan Kontrasepsi Jangka Panjang di Wilayah Kerja Puskesmas Cigalontang Kabupaten Tasikmalaya tahun 2018

\begin{tabular}{|c|c|c|c|c|c|c|c|c|}
\hline \multirow{3}{*}{$\begin{array}{l}\text { Dukungan } \\
\text { Suami }\end{array}$} & \multicolumn{4}{|c|}{ Penggunaan kontrasepsi } & \multirow{2}{*}{\multicolumn{2}{|c|}{ Total }} & \multirow{3}{*}{$\begin{array}{c}\mathrm{P} \\
\text { value }\end{array}$} & \multirow{3}{*}{ OR } \\
\hline & \multicolumn{2}{|c|}{ MKJP } & \multicolumn{2}{|c|}{ Non MKJP } & & & & \\
\hline & $\mathbf{F}$ & $\%$ & $\overline{\mathbf{F}}$ & $\%$ & Jml & $(\%)$ & & \\
\hline Positif & 54 & $\begin{array}{l}23 . \\
3\end{array}$ & 178 & 76.7 & 232 & 100 & 0,000 & 3,784 \\
\hline Negatif & 19 & 7.4 & 237 & 92.6 & 256 & 100 & & \\
\hline Jumlah & 73 & 15 & 415 & 85 & 448 & 100 & & \\
\hline
\end{tabular}

Data pada tabel 3.13 menunjukkan bahwa responden yang mendapat dukungan positif dari suami terhadap penggunaan kontrasepsi jangka panjang sebanyak 178 orang $(76.7 \%$ ) tidak menggunakan kontrasepsi jangka panjang dan responden sebanyak 237 orang (92.6\%) mendapat dukungan negatif dari suami terhadap kontrasepsi jangka panjang tidak menggunakan kontrasepsi jangka panjang. Berdasarkan hasil analisis didapat $\mathrm{p}$ value sebesar 0,000 artinya terdapat hubungan antara dukungan suami dengan penggunaan metode kontrasepsi jangka panjang. Responden yang mendapat dukungan positif dari suami berpeluang sebesar 3.784 kali untuk menggunakan kontrasepsi jangka panjang dibandingkan dengan responden yang tidak mendapat dukungan sumai untuk menggunakan kontrasepsi jangka panjang. 


\section{PEMBAHASAN}

\section{Penggunaan Kontrasepsi Jangka Panjang (MKJP)}

Metode Kontrasepsi Jangka Panjang (MKJP) merupakan metode kontrasepsi yang masa pemakaiannya lama serta efektivitas tinggi terhadap pencegahan kehamilan, yang terdiri dari implant atau sering disebut susuk KB, AKDR/IUD, MOP, dan MOW (BKKBN, 2011). Sementara pada Puskesmas Cigalontang pelayanan MKJP terbatas pada AKDR dan implan atau susuk.

Berdasarkan data hasil penelitian menunjukkan bahwa sebagian besar responden tidak menggunakan metode kontrasepsi jangka panjang sebanyak 415 orang $(15 \%)$, dan terdapat 73 orang $(85 \%)$ responden menggunakan metode kontrasepsi jangka panjang, adapun distribusi responden yang menggunakan metode kontrasepsi jangka panjang adalah MOW sebanyak 5 orang $(6,85 \%)$, IUD sebanyak 45 orang $(61,65 \%)$, dan implant sebanyak 23 orang $(31,5 \%)$. Hal ini sesuai dengan hasil studi pendahuluan melalui data sekunder yang menunjukkan bahwa proporsi akseptor KB non MKJP di Puskesmas Cigalontang adalah 91,8\%, artinya proporsi pengguna MKJP masih jauh dari target yaitu hanya $8,2 \%$

sedangkan secara nasional target pencapaian KB aktif MKJP berada di 23,5 \% (Laporan Kinerja Instansi Pemerintah 2015, BKKBN.2016).

Berdasarkan data dari BPS Kab Tasikmalaya tahun 2015 bahwa jumlah penduduk di kecamatan cigalontang adalah yang terbesar diantara kecamatan yang ada di Kab Tasikmalaya yaitu sebesar 70,101 jiwa dengan kepadatan sebesar 585 penduduk $/ \mathrm{km}^{2}$, ditunjang dengan data bahwa sebagian besar responden akseptor KB non MKJP mempunyai tujuan penggunaan kontrasepsinya adalah membatasi yaitu 220 orang (53\%) dan menunda yaitu 116 orang (28\%) dari data tersebut menunjukkan bahwa responden masih berkeinginan untuk mempunyai anak lagi, dengan demikian besar

kemungkinan wilayah cigalontang mempunyai peluang yang besar untuk menambah jumlah penduduk.

Jika permalahan jumlah penduduk tidak segera teratasi dengan terus bertambahnya jumlah kelahiran diwilayah tersebut, maka kemungkinan besar berbagai permasalahan akan terjadi terutama masalah kesehatan. Permasalahan pertumbuhan penduduk dapat diatasi dengan penggunaan kontrasepsi yang tepat karena akan menekan angka kelahiran. Sesuai dengan UU Nomor 52 Tahun 2009 tentang perkembangan kependudukan dan pembangunan keluarga menyebutkan bahwa keluarga berencana adalah upaya untuk mengatur kelahiran anak, jarak, dan usia ideal melahirkan, mengatur kehamilan, melalui promosi, perlindungan, dan bantuan sesuai hak reproduksi untuk mewujudkan keluarga yang berkualitas (Buletin Jendela Data dan Informasi, 2013).

\section{Hubungan Pengetahuan dengan penggunaan MKJP}

Hasil penelitian menunjukkan bahwa lebih dari separuh sebanyak 277 orang (56.8\%) akseptor KB aktif di Wilayah Puskesmas Cigalontang Tahun 2018 memiliki pengetahuan MKJP yang kurang baik. Pada analisa bivariat diperoleh informasi bahwa dari 277 akseptor aktif di wilayah kerja Puskesas Cigalontang yang mempunyai pengetahuan kurang baik, 87

$\%$ diantaranya menggunakan kontrasepsi non MKJP. Berdasarkan hasil analisis didapat $\mathrm{p}$ value sebesar 0,164 artinya tidak ada hubungan antara pengetahuan dengan penggunaan metode kontrasepsi jangka panjang. 
Hasil penelitian menunjukkan bahwa distribusi pengetahuan responden akseptor KB MKJP antara yang berpengetahuan baik dan kurang hampir sama, sedangkan distribusi pengetahuan responden akspetor KB non MKJP lebih dari setengah responden tergolong kurang. Pengetahuan dikatakan baik apabila responden dapat menjawab minimal 8 pertanyaan dari 11 pertanyaan. Pengetahuan yang kurang terlihat dari jawaban responden yang meliputi bahwa sebagian responden tidak dapat membedakan jenis-jenis MKJP antara suntik pil dengan IUD, implant, MOW. Selanjutnya responden kurang mengetahui bahwa pemasangan IUD dapat dilakukan pada perempuan yang sedang haid, dan yang terakhir responden tidak mengetahui bahwa bagi pengguna IUD disarankan untuk mengecek benang IUD sendiri setelah selesai haid.

Jika disimpulkan bahwa pengetahuan responden tentang MKJP sudah tergolong baik pada seputar pertanyaan tentang Tubektomi dan efeksamping, sementara terkait jenis-jenis MKJP tergolong kurang baik. Dengan demikian perlu adanya peningkatan pengetahuan akseptor $\mathrm{KB}$ terkait alat kontrasepsi MKJP.

Hasil penelitian menunjukkan bahwa distribusi responden pengguna MKJP antara yang memiliki pengetahuan baik dan kurang hampir sama, namun demikian responden pengguna non MKJP pun banyak yang mempunyai pengetahuan kurang. Hasil tersebut diperkirakan menjadi alasan tidak adanya hubungan yang signifikan antara pengetahuan dengan penggunaan MKJP.

Dari data tersebut menunjukan bahwa pengetahuan yang baik belum tentu dapat membuat seseorang menggunakan kontrasepsi MKJP, begitupun seseorang yang mempunyai pengetahuan kurang mempunyai kemungkinan untuk menggunakan kontrasepsi MKJP, hal ini menunjukkan ada variabel lain yang dapat mempengaruhi penggunaan MKJP.

Pengetahuan merupakan aspek penting dalam perubahan perilaku seseorang, karena hal tersebut diperlukan sebagai dorongan fisik dalam menumbuhkan rasa percaya diri maupun dengan dorongan sikap perilaku setiap orang, sehingga dapat dikatakan bahwa pengetahuan merupakan stimulasi terhadap tindakan seseorang (Notoatmodjo, 2005). Tetapi dalam hal ini tidak lagi menjadi aspek yang berpengaruh untuk merubah perilaku seseorang sejalan dengan penelitian Ismi Dzalva (2015) diketahui bahwa variabel pengetahuan tidak memiliki hubungan yang signifikan dengan penggunaan MKJP, namun bisa

kemungkinan tahapan pengetahuan responden saat ini hanya sampai pada tahapan tahu saja belum sampai proses memahami sehingga akan berpengaruh terhadap perubahan perilaku, sejalan dengan teori Notoatmodjo (2005) bahwa tingkatan pengetahuan dimulai dari tahu yang kedua memahami yang ketiga aplikasi keempat analisa kelina sintesis dan terakhir dapat menganalisa, memang saat ini perkembangan teknologi sangat pesat masyarakat bisa saja mendapat infromasi dari berbagai akses seperti dari media social, internet yang hampir

sebagian besar masyarakat sudah mengenal teknologi tersebut.

Meskipun tidak terdapat hubungan antara pengetahuan dengan penggunaan MKJP, namun diketahui lebih banyak responden yang memiliki pengetahuan kurang dibandingkan pengetahuan baik. oleh karena itu perlu upaya untuk meningkatkan pengetahuan masyarakat mengenai MKJP sampai tahapan minimal dapat memahami sehingga mempermudah dalam memilih alat kontrasepsi yang tepat, salah satu upaya nya adalah tidak hanya sekedar proses penyampaian informasi seperti konseling tetapi bagaimana mengemas media yang efektif berupa video pembelajaran dalam rangka meningkatkan pemahaman masyarakat tidak hanya sekedar tahu saja. 


\section{Hubungan Sikap dengan penggunaan MKJP}

Hasil penelitian di wilayah kerja Puskesmas Cigalontang menunjukkan bahwa sebagian besar akseptor KB aktif di wilayah tersebut memiliki sikap negatif terhadap penggunaan kontrasepsi MKJP, dan sebagian hanya kecil yang memiliki sikap positif. Pada variabel ini diberikan pertanyaan tentang prosedur, efek samping dan penatalaksanaan penggunaan MKJP. Pada analisa bivariate, dapat diketahui pengguna non MKJP di wilayah kerja puskesmas cigalontang lebih banyak yang memiliki sikap negatif $(97,5 \%)$ terhadap penggunaan MKJP dibandingkan dengan yang memiliki sikap postif ( $2,5 \%)$. Uji statistic didapat $\mathrm{p}$ value sebesar 0,071 artinya tidak ada hubungan antara pengetahuan dengan penggunaan metode kontrasepsi jangka panjang di wilayah kerja puskesmas cigalontang Kecamatan Cigalontang Kabupaten Tasikmalaya.

Hasil penelitian diketahui dikatakan sikap positif jika skor nilai lebih dari 30 , dari 10 pertanyaan sikap, 4 pertanyaan

yang dianggap menjadi sebuah permasalahan yaitu banyak responden mengatakan setuju bahwa adanya proses pembedahan yang dilakukan pada pemasangan implant dapat menimbulkan ketakutan pada calon akseptor KB, banyak responden setuju bahwa prosedur

pemeriksaan orgam intim pada pemasangan IUD memberikan rasa ketidaknyamanan pada akseptor IUD, banyak responden mengatakan tidak setuju bahwa pemasangan MKJP tidak mengurangi keharmonisan hubungan suami istri, serta banyak responden tidak menyutujui bahawa penggunaan metode

kontrasepsi jangka panjang tidak memerlukan kontrol rutin pada petugas kesehatan. Sehingga dari beberapa pernyataan tersebut diatas banyak persepsi yang salah terhadap penggunaan kontrsepsi metode jangka panjang terutama IUD dan implant, sejalan dengan pernyataan Affandi Biran (BKKBN, 2006) bahwa salah satu keuntungan penggunaan IUD adalah tidak mengganggu hubungan suami istri karena tidak perlu takut untuk hamil sehingga dapat meningkatkan kenyamanan seksual, serta pengguna IUD dapat melakukan pemeriksaan AKDR setiap tahun atau bila terdapat keluhan.

Hasil penelitian menunjukkan bahwa baik pengguna MKJP dan pengguna non MKJP mempunyai sikap lebih banyak negatif terhadap penggunaan kontrasepsi MKJP dibandingkan dengan sikap yang positif. Dengan demikian baik yang mempunyai sikap negatif maupun sikap

positif sama-sama belum tentu menggunakan MKJP oleh karena itu dapat dijadikan kemungkinan tidak adanya hubungan antara sikap dengan penggunaan MKJP, sejalan dengan penelitian dari Ismi Dzalva (2015) diketahui bahwa variabel sikap tidak memiliki hubungan yang signifikan dengan penggunaan MKJP.

Dari data tersebut menunjukkan bahwa sikap seseorang yang positif terhadap metode kontrasepsi jangka panjang belum tentu menggunakan MKJP, oleh karena itu perlu upaya yang keras dalam rangka meningkatkan cakupan penggunaan MKJP dengan kerjasama lintas sektor.

\section{Hubungan Pekerjaan dengan penggunaan MKJP}

Hasil penelitian di wilayah PKM Cigalontang menunjukkan bahwa sebagian besar akseptor $\mathrm{KB}$ aktif dengan status tidak bekerja yaitu sebanyak $86,7 \%$, dan sebagian kecil yang bekerja yaitu sebanyak 13,3 \%. Pada analisa bivariat diketahui bahwa akseptor pengguna non MKJP sebagian besar tidak bekerja yaitu sebanyak 369 orang $(87,4 \%)$ begitu pula dengan akseptor pengguna MKJP sebagian besar responden tidak bekerja yaitu sebanyak 20 orang $(30,8 \%)$.

Uji statistic didapatkan analisis didapat $p$ value sebesar 0,000 artinya terdapat hubungan antara pekerjaan dengan penggunaan metode kontrasepsi jangka panjang. Responden yang bekerja 
berpeluang sebesar 3.094 kali untuk menggunakan kontrasepsi jangka panjang dibandingkan dengan responden yang tidak bekerja.

Data di atas sejalan dengan penelitian Desi tahun 2016 yang dilakukan di Kecamatan Gondokusuman bahwa Hasil uji chi square memberikan kesimpulan variabel pekerjaan berhubungan dengan penggunaan kontrasepsi $(\mathrm{p}=0,000)$.

Berdasarkan uraian diatas penulis berpendapat bahwa pengguna non MKJP sebagian besar tidak bekerja, hal tersebut dapat disebabkan oleh karena akseptor KB yang bekerja memiliki kesempatan untuk memperoleh informasi baik dari teman kerja atau dari media lain sehingga kesempatan untuk menggunakan MKJP dapat lebih besar dibandingkan dengan akseptor yang tidak bekerja. Selain itu, akseptor KB yang bekerja juga mempertimbangkan berbagai hal seperti waktu, pemakaian KB jangka pendek (Non MKJP) yang harus diminum tiap hari seperti pil atau tiap bulan seperti suntik yang dapat menyita banyak waktu serta tidak efektif. Sejalan dengan pernyataan

Fienalia (2012), wanita bekerja kemungkinan lebih menyadari kegunaan dan manfaat $\mathrm{KB}$ serta lebih mengetahui pilihan metode yang ada jika dibandingkan dengan wanita yang tidak bekerja.

\section{Hubungan Paritas dengan penggunaan MKJP}

Paritas atau jumlah anak yang pernah dilahirkan merupakan salah satu indikator dalam menentukan pilihan kontrasepsi yang tepat, sejalan dengan Hal ini sejalan dengan BBKN (2007) Jumlah anak hidup mempengaruhi pasangan usia subur dalam menentukan metode kontrasepsi yang akan digunakan. Pada pasangan dengan jumlah anak hidup masih sedikit terdapat

kecenderungan untuk menggunakan metode kontrasepsi dengan efektivitas rendah, sedangkan pada pasangan dengan jumlah anak hidup banyak terdapat kecenderungan menggunakan.metode kontrasepsi dengan efektivitas jangka panjang.

Hasil penelitian menunjukkan bahwa sebagian besar akseptor $\mathrm{KB}$ diwilayah kerja PKM Cigalontang memiliki jumlah anak yang ideal yaitu kurang dari sama dengan 2 sebanyak 306 orang (62,7\%), dan sebagian kecil akseptor KB aktif dengan jumlah anak tidak ideal yaitu lebih dari 2 sebanyak 182 orang $(37,3)$. Pada analisa bivariate menunjukkan bahwa akseptor pengguna non MKJP sebagian besar memiliki jumlah anak ideal yaitu 67 $\%$ meski demikian masih ada akseptor non MKJP yang memiliki anak tidak ideal yaitu $33 \%$.

Uji statistik didapat $\mathrm{p}$ value sebesar 0,000 artinya terdapat hubungan antara paritas dengan penggunaan metode kontrasepsi jangka panjang. Responden dengan paritas tidak ideal berpeluang sebesar 0.307 kali untuk menggunakan kontrasepsi jangka panjang dibandingkan dengan responden dengan paritas ideal. Hal tersebut sejalan dengan penelitian puji laksmini dengan judul faktor-faktor yang berhubungan dengan penggunaan MKJP di Pulau Jawa Tahun 2012 Desain penelitian yang digunakan cross sectional dengan jumlah sampel 5257 responden dan dianalisis dengan complex samples. Data didapatkan dari data sekunder SDKI 2012. Dengan hasil jumlah anak hidup atau

paritas, merupakan variabel yang berhubungan dengan penggunaan MKJP.

Berdasarkan data di atas paritas menjadi salah satu faktor yang penting dalam menentukan pilihan metode kontrasepsi yang tepat, meskipun data menunjukkan bahwa sebagian akseptor KB aktif mempunyai jumlah anak ideal tetapi yang harus menjadi perhatian adalah masih banyak akseptor KB non MKJP dengan jumlah anak yang tidak ideal bahkan ada akseptor KB suntik dengan umur lebih dari 42 tahun dan jumlah anak 7 orang dengan kondisi tersebut dapat menambah jumlah resiko terjadi permasalahan ketika hami bersalin dan nifas, sejalan dengan penelitian Psiari P.K (2017) dengan judul 
faktor-faktor yang berhubungan dengan kejadian perdarahan pasca salin didapatkan hasil bahwa variabel yang berhubungan dengan kejadian perdarahan pasca salin adalah paritas dan usia.

Dari data diatas dapat disimpulkan bahwa perlu upaya untuk dapat membatasi jumlah kelahiran sehingga dapat mengurangi resiko yang terjadi selain itu semakin banyak anak semakin banyak pula tanggungan kepala keluarga dalam mencukupi kebutuhan materil dan untuk menjaga kesehatan sistem reproduksi oleh karena itu salah satu upayanya adalah dengan penggunaan kontrasepsi yang tepat.

\section{Hubungan Status Sosio ekonomi dengan penggunaan MKJP}

Hasil penelitian menunjukkan sebagian besar status sosio ekonomi akseptor KB aktif di wilayah kerja PKM Cigalontang berada di bawah UMK (upah minimum kabupaten), yaitu 90,8 \% dan hanya 9,2 persen status sosio ekonomi akseptor $\mathrm{KB}$ aktif yang berada di atas UMK. Pada analisa bivariate diketahui bahwa status ekonomi akseptor pengguna non MKJP sebagian besar berada di bawah UMK yaitu 385 orang $(02,8 \%)$, begitu juga status sosio ekonomi akseptor pengguna MKJP sebagian besar berada di bawah UMK yaitu 58 orang $(79,5 \%)$.

Uji statistik didapat $p$ value sebesar 0,013 artinya terdapat hubungan antara paritas dengan penggunaan metode kontrasepsi jangka panjang. Responden dengan status ekonomi diatas UMR berpeluang sebesar 3.319 kali untuk menggunakan kontrasepsi jangka panjang dibandingkan dengan responden dengan status ekonomi dibawah UMR.

Data diatas sejalan dengan penelitian puji laksmini yang dilakukan di Gondokusumo tahun 2016 dengan judul penelitian faktor-faktor yang berhubungan dengan penggunaan MKJP di Pulau Jawa Tahun 2012 didapatkan hasil bahwa status sosio ekonomi adalah salah satu variabel yang mempunyai hubungan signifikan dengan penggunaan MKJP.

Dari data diatas menunjukkan bahwa pendapatan seseorang menentukan dalam pengambilan keputusan untuk memilih menggunakan kontrasepsi karena dalam hal penggunaan kontrasepsi perlu dana yang harus disiapkan meskipun harga untuk penggunaan kontrasepsi tidak sama kemungkinan metode non MKJP banyak dipilih seperti suntik oleh sebagian responden karena dirasa murah meskipun penggunaannya jangka pendek karena harus melakukan prosedur ulangan untuk menggunakannya, sedangkan MKJP memerlukan persiapan dana yang cukup meskipun sebetulnya MKJP merupakan kontrasepsi jangka panjang dan tidak ada proses ulangan sehingga secara ekonomi sebetulnya lebih hemat dibandingkan dengan non MKJP serta pemerintah sudah banyak menggalakan program pemasangan alat kontrasepsi gratis di tiap wilayah seperti IUD, implant dan MOW tetapi animonya masih sedikit dibandingkan dengan metode non MKJP.

Dari permasalahan di atas dapat disimpulkan bahwa status sosio ekonomi mempunyai peran yang penting dalam

keberhasilan meningkatkan cakupan kontrasepsi MKJP sehingga perlu upaya yang lebih tidak hanya sekedar program rutin memberikan pelayanan $\mathrm{KB}$ gratis tetapi perlu upaya dalam persiapannya

seperti pelayanan konseling yang berkualitas sehingga calon akseptor mendapat pemahaman lebih tentang keuntungan dan kerugian penggunaan kontrasepsi dan dapat memilih metode yang tepat sesuai kebutuhan.

\section{Hubungan Dukungan suami dengan penggunaan MKJP}

Hasil penelitian menunjukkan lebih dari separuh dukungan suami akseptor $\mathrm{KB}$ aktif di wilayah PKM Cigalontang terhadap penggunaan MKJP adalah negatif yaitu 52,5\%. Pada analisa bivariat didapat bahwa 
dukungan suami akseptor non MKJP adalah negatif yaitu 237 orang $(57,1 \%)$ dan 178 orang $(42,9 \%)$ yang mendapat dukungan positif. Sedangkan akseptor KB pengguna MKJP sebagian besar dukungan suami adalah positif yaitu 54 orang ( $74 \%$ ), dan sebagian kecil dengan dukungan negatif yaitu 19 orang (26\%).

Uji statistik didapat didapat $\mathrm{p}$ value sebesar 0,000 artinya terdapat hubungan antara dukungan suami dengan penggunaan metode kontrasepsi jangka panjang. Responden yang mendapat dukungan positif dari suami berpeluang sebesar 3.784 kali untuk menggunakan kontrasepsi jangka panjang dibandingkan dengan responden yang tidak mendapat dukungan suami untuk menggunakan kontrasepsi jangka panjang.

Sejalan dengan penelitian Mahmudah LT yang dilakukan di Semarang tahun 2015 dengan judul faktor yang berhubungan dengan pemilihan MKJP pada akseptor $\mathrm{KB}$ wanita di Kecamatan Banyubiru didapatkan hasil bahwa variabel dukungan suami merupakan salah satu varibel yang memberikan hubungan yang signifikan dengan penggunaan kontrasepsi MKJP.

Dukungan suami terhadap penggunaan MKJP di wilayah PKM Cigalontang tergolong kurang baik dimana dari 6 pertanyaan ada 2 pertanyaan yang sebagian besar berada pada kategori negatif yaitu pertanyaan no 1 bahwa sebagian besar suami lebih menyukai istri menggunakan metode jangka pendek yaitu sebesar 70,3\% dan pertanyaan no 6 bahwa sebagian besar suami lebih menyarakan istri untuk menggunakan metode yang mudah dihentikan yaitu sebesar 79,7 \%.

Dari dapat tersebut menunjukkan bahwa para suami di wilayah kerja PKM cigalontang memberikan pengaruh yang tinggi terhadap penggunaan kontrasepsi, dimana ternyata bahwa para suami lebih setuju dengan kontrasepsi jangka pendek dibandingkan dengan kontrasepsi jangka panjang, ditambah kemungkinan dari aspek pengambilan keputusan dimana suami masih memegang kendali.

Peran suami sangat penting dalam penggunaan kontrasepsi, penggunaan kontrasepsi merupakan tanggung jawab bersama pria dan wanita sebagai pasangan, sehingga metode kontrasepsi yang dipilih mencerminkan kebutuhan serta keinginan suami dan istri. Suami dan istri harus saling mendukung dalam penggunaan metode kontrasepsi karena keluarga berencana dan kesehatan reproduksi bukan hanya urusan pria atau wanita saja (BKKBN, 2001).

Dukungan dari suami dalam penggunaan kontrasepsi sangat diperlukan karena tanpa adanya dukungan dari suami rasa nyaman untuk menggunakan kontrasepsi tidak akan didapatkan, metode kontrasepsi tidak dapat dipaksakan pasangan suami isteri harus bersama memilih metode kontrasepsi yang terbaik, saling kerjasama dalam pemakaian, membiayai pengeluaran kontrasepsi, dan memperhatikan tanda dan bahaya. (Mahmudah 1.T, 2015).

Dari data diatas dapat disimpulkan bahwa suami mempunyai peran yang sangat penting dalam penggunaan

kontrasepsi perlu upaya dalam meningkatkan partisipasi suami dalam ber KB seperti selalu melibatkan suami dalam berbagai hal terutama dalam proses konseling $\mathrm{KB}$, suami perlu dilibatkan dalam hal pengambilan keputusan dalam memilih metode kontrasepsi yang tepat.

Dari pembahasan di atas dapat disimpulkan bahwa diantara 6 variabel yang diteliti variabel dukungan suami yang baik memiliki peluang yang paling tinggi diantara variabel yang lain untuk menggunakan kontrasepsi MKJP dengan nilai OR 3,874 artinya akseptor KB yang mempunyai dukungan suami yang positif terhadap MKJP mempunyai peluang 3, 874 kali lebih tinggi menggunakan MKJP disbanding yang tidak mendapat dukungan yang positif. Dengan demikian perlu upaya dalam meningkatkan partisipasi suami dalam ber KB yaitu dengan memberikan 
pemahaman tentang metode kontrasepsi melalui konseling $\mathrm{KB}$, sejalan dengan penelitian Sulistiyaningsih SH (2017) bahwa hasil uji statistik chi square didapatkan ada hubungan efektifitas konseling KB terhadap pengetahuan PUS dalam pemilihan alat kontrasepsi IUD.

Disamping itu dukungan dari tenaga kesehatan juga sangat diperlukan dalam meningkatkan cakupan MKJP dalam hal peningkatan konseling KB karena dari data penelitian didapatkan hasil bahwa beberapa responden $(29,1 \%)$ mengatakan petugas kesehatan tidak selalu menggunakan media alat bantu pengambilan keputusan dalam konseling KB padahal media tersebut sangat direkomendasikan dalam upaya peningkatan cakupan KB. Selain itu berdasarkan hasil penelitian responden sebanyak 16,6 \% mengatakan masih kurang paham dengan penjelasan tentang metode kontrasepsi dari petugas kesehatan oleh karena perlu peningkatan pengetahuan tenaga kesehatan dengan kegiatan pelatihan mengenai teknik konseling KB.

\section{F. SIMPULAN DAN SARAN}

\section{Simpulan}

Berdasarkan hasil penelitian dan pembahasan Faktor-Faktor Yang Berhubungan Dengan Partisipasi Akseptor KB Aktif Terhadap Penggunaan Kontrasepsi Jangka Panjang Di Desa Cigalontang Wilayah Kerja Puskesmas Cigalontang Tahun 2018, maka penulis dapat menyimpulkan sebagai berikut:

a. Tidak ada hubungan faktor pengetahuan terhadap penggunaan alat kontrasepsi jangka panjang di wilayah kerja puskesmas cigalontang kabupaten tasikmalaya tahun 2018 , dengan $p$ value sebesar 0.164 .

b. Tidak ada hubungan faktor sikap terhadap penggunaan alat kontrasepsi jangka panjang di wilayah kerja

puskesmascigalontangkabupaten tasikmalaya tahun 2018, dengan $p$ value 0,071 .

c. Ada hubungan faktor pekerjaan terhadap penggunaan alat kontrasepsi jangka panjang di wilayah kerja

puskesmas cigalontang kabupaten tasikmalaya tahun 2018, dengan $p$ value sebesar 0.000 dengan nilai OR 3,094

artinya Responden yang bekerja berpeluang sebesar 3.094 kali untuk menggunakan kontrasepsi jangka panjang dibandingkan dengan responden yang tidak bekerja.

d. Ada hubungan paritas terhadap penggunaan alat kontrasepsi jangka panjang di wilayah kerja puskesmas cigalontang kabupaten tasikmalaya tahun 2018, dengan $p$ value sebesar 0.000 dan nilai OR 0,307 artinya responden dengan paritas tidak ideal berpeluang sebesar

0.307 kali untuk menggunakan kontrasepsi jangka panjang dibandingkan dengan responden dengan paritas ideal.

e. Ada hubungan faktor status sosio ekonomi terhadap penggunaan alat kontrasepsi jangka panjang di wilayah kerja puskesmas cigalontang kabupaten tasikmalaya tahun 2018, dengan $p$ value sebesar 0.000 dan nilai OR 3,319 artinya responden dengan status sosio ekonomi diatas UMR berpeluang sebesar 3.319 kali untuk menggunakan kontrasepsi jangka panjang dibandingkan dengan responden dengan status ekonomi dibawah UMR.

f. Ada hubungan faktor dukungan suami terhadap penggunaan alat kontrasepsi jangka panjang di wilayah kerja puskesmas cigalontang kabupaten tasikmalaya tahun 2018 , dengan $p$ value sebesar 0.000 dengan nilai OR 3,784 artinya responden yang mendapat dukungan positif dari suami berpeluang sebesar 3.784 kali untuk menggunakan kontrasepsi jangka panjang dibandingkan dengan responden yang tidak mendapat dukungan sumai untuk menggunakan kontrasepsi jangka panjang. 


\section{Saran}

Berdasarkan hasil penelitian maka penulis dapat memberikan saran sebagai berikut:

a. Responden

PUS dapat berperan serta dalam meningkatkan cakupan penggunaan kontrasepsi jangka panjang dengan keterlibatan dalam penggunaan kontrasepsi jangka panjang, selain itu untuk meningkatkan pengetahuan pasangan usia subur dapat secara aktif berperan serta mengikuti kegiatankegiatan atau program kesehatan baik yang diselenggarakan oleh pemerintah atau puskesmas ataupun seperti aktif dalam kegiatan Posyandu atau kegiatan lain seperti penyuluhan, bimbingan dan konseling yang akhirnya dapat memilih kontrasepsi sesuai dengan tujuannya. Selain itu untuk para suami khususnya dapat ikut berperan serta dalam KB dengan ikut mendampingi istri untuk dapat menentukan metode kontrasepsi yang tepat.

b. Bagi Tenaga Kesehatan

Meningkatkan keterampilan dalam hal komunikasi konseling KB kepada pasangan usia subur dengan aktif mengikuti kegiatan pelatihan, serta selalu mengajak para suami untuk dapat berpartisipasi dalam ber $\mathrm{KB}$ dengan ikut mendampingi istri pada saat konseling $\mathrm{KB}$ sehingga dapat ikut menentukkan metode kontrasepsi yang tepat.

c. Bagi Puskesmas

Dapat menggerakan seluruh masyarakatnya untuk aktif dalam ber $\mathrm{KB}$ terutama dalam penggunaan metode kontrasepsi jangka panjang, dengan meningkatkan kegiatan penyuluhan secara berkala dan berkesinambungan.

d. Bagi Dinas Kesehatan

Mengoptimalisasi kegiatan safari KB yang sudah dilakukan secara berkala dilakukan secara rutin dan memfasilitasi tenaga kesehatan untuk terusdapatmeningkatkan keterampilannya dengan

penyelenggaraan pelatihan.

e. Bagi Pemerintah

Perlu inovasi dalam hal penggunaan kontrasepsi, dengan memfasilitasi para peneliti untuk dapat melakukan penelitian tentang menciptakan metode kontrasepsi yang efektif, dan mudah penggunaannya.

f. Bagi Institusi Pendidikan

Institusi pendidikan dapat memperkaya literature tentang kontrasepsi di perpustakaan, serta dapat menjadi wadah dalam mendukung kegiatan penelitian selanjutnya dalam hal dana penelitian.

g. Bagi Peneliti

Melaksanakan penelitian sesuai dengan permasalahan yang ditemukan pada penelitian sebelumnya yaitu membuat media atau video pembelajaran yang dikemas secara menarik dan mudah dalam hal penggunaannya untuk dapat meningkatkan pemahaman para calon akseptor KB sehingga harapannya dapat memilih metode kontrasepsi yang tepat terutama metode kontrasepsi jangka panjang. 


\section{G. REFERENSI}

Asih, Leli, Hadriah Oesman (2009). Analisis Lanjut SKDI 2007 Faktor yang Mempengaruhi Pemakaian Kontrasepsi Jangka Panjang (MKJP). Jakarta : BKKBN

Badan Pusat Statistik Kabupaten Tasikmalaya Tahun 2015

BKKBN, 2011. Profil Hasil

Pendataan Keluarga Tahun 2011. Jakarta: Badan Kependudukan dan Keluarga Berencana Nasional Direktorat Pelaporan dan Statistik.

BKKBN. (2001). Program keluarga berencana nasional. Jakarta: BKKBN

BKKBN. (2007). Keluarga Berencana dan kontrasepsi. Cetakan ke-5. Jakarta. Pustaka sinar harapan

BKKBN. 2005. Keluarga Berencana dan Kesehatan Reproduksi. Jakarta: BKKBN.

Buletin Pusat Data dan Informasi Kesehatan 2013.

Data Kesehatan Dinas Kabupaten Tasikmalaya Tahun 2016.

Desi, 2016. Faktor-Faktor Yang

Berhubungan Dengan Penggunaan Metode Kontrasepsi Jangka Panjang Di Wilayah Kerja Puskesmas Gondokusuman. Yogyakarta. Diakses tanggal 13 Februari 2019.

Ekarini, Sri Madya Bhakti. 2008.

Analisis Faktor-Faktor yang Berpengaruh terhadap Partisipasi Pria dalam Keluarga Berencana di Kecamatan Selo Kabupaten Boyolali.

Tesis. Universitas Diponegoro. Semarang.

Endang. Buku Sumber Keluarga Berencana, Kesehatan Reproduksi,

Gender, dan Pembangunan Kependudukan. BKKBN \& UNFPA. Jakarta. 2002.

Endy.M.Meogni dkk.2013

Pelayanan Kesehatan Ibu di Fasilitasi

Kesehatan Dasar dan Rujukan.Jakarta: WHO Country Office for Indonesia
Fienalia, R.A. 2012. Faktorfaktor yang Berhubungan dengan

Penggunaan Metode Kontrasepsi Jangka Panjang (MKJP) di Wilayah Kerja Puskesmas Pancoran Mas Kota Depok Tahun 2011. (Skripsi). Universitas Indonesia. Jakarta.

Ismi Dzalva, 2015. FaktorFaktor Yang Berhubungan Dengan

Penggunaan Metode Kontrasepsi Jangka Panjang Di Wilayah Kerja Puskesmas Kecamatan Kalideres Tahun 2015. Jakarta. Diakses tanggal 13 Februari 2019.

Laporan Kinerja Instansi

Pemerintah 2015, Badan

Kependudukan dan keluarga

Berencana, 2016

Mahmudah LT, 2014. Analisis Faktor Yang Berhubungan Dengan Pemilihan Metode Kontrasepsi Jangka Panjang (MKJP) Pada Akseptor KB Wanita Di Kecamatan Banyubiru Kabupaten Semarang. Unnes Journal Of Public Health. Diakses tanggal 13 Februari 2019.

Manuaba, IAC., I Bagus, dan IB Gde. 2010. Ilmu Kebidanan, Penyakit Kandungan dan KB untuk Pendidikan Bidan. Edisi kedua. Jakarta: EGC.

Notoatmodjo, S. 2007. Pendidikan dan Perilaku kesehatan Cetakan 2. Jakarta:PT. Rineka Cipta

Notoatmodjo, Soekidjo. 2003. Pendidikan Dan Perilaku Kesehatan. Rineka Cipta. Jakarta.

Notoatmodjo, Soekidjo. 2010. Metodologi Penelitian Kesehatan. Rineka Cipta. Jakarta.

Notoatmodjo,s. 2005. Metodologi penelitian kesehatan. Jakarta : PT Rineka Cipta.

Notoatmodjo. 2005. Promosi Kesehatan: Ilmu dan Seni. Rhineka Cipta. Jakarta.

Psiari, 2017. Faktor-Faktor Yang Menyebabkan Terjadinya Perdarahan Pasca Persalinan. 
JurnalIlmu Kesehatan Aisyah. Diakses tanggal 13 Februari 2019.

Puji aksmini, 2012. Faktor-

Faktor Yang Berhubungan Dengan

Penggunaan Metode Kontrasepsi Jangka Panjang di Pulau Jawa (Analisis Data SDKI 2012). Diakses tanggal 13 Februari 2019.

$$
\text { Purwoastuti,Th Endang }
$$

dkk.2015. Panduan Kesehatan Reproduksi Dan Keluarga Berencana. Yogyakarta : pustaka baru press

Purwoko. 2000. Tesis

Penerimaan Vasektomi dan Sterilisasi Tuba. Fakultas Kedokteran Undip. Semarang.

Saifuddin, Abdul Bari. 2006.

Buku Panduan Praktis Pelayanan
Kesehatan Maternal dan Neonatal, Jakarta: Yayasan Bina Sarwono Prawirohardjo.

Sulistiyaningsih Sri Hadi, 2017. Efektifitas Konseling KB Terhadap Pengetahuan dan Sikap PUS dalam Pemilihan Metode Kontrasepsi Intra Uterine Device (IUD). Jurnal Maternal Vol II No 2. 2017. Diakses tanggal 13 Februari 2019.

Suprihastuti, dkk. 2000. Analisis Data Sekunder SDKI 97 Pengambilan Keputusan Penggunaan Alkon Pria di Indonesia. D.I. Yogyakarta.

Widyatun Diah. 2012. Program KB di Indonesia.http://jurnalbidandiah.blogsp ot.co.id/2012/07/program-kb-diindonesi 